\title{
Maritime Security: A New Strategy for Merchant Shipping to Avoid Piracy in the Gulf of Guinea
}

\author{
Debi Ahoefa Broohm, Guohua Wang, Juntao Gao \\ School of Law, Shanghai Maritime University, Shanghai, China \\ Email: octaviebroohm@yahoo.com
}

How to cite this paper: Broohm, D. A., Wang, G. H., \& Gao, J. T. (2020). Maritime Security: A New Strategy for Merchant Shipping to Avoid Piracy in the Gulf of Guinea. Open Journal of Social Sciences, 8, 392-410. https://doi.org/10.4236/jss.2020.85027

Received: April 2, 2020

Accepted: May 26, 2020

Published: May 29, 2020

Copyright $\odot 2020$ by author(s) and Scientific Research Publishing Inc. This work is licensed under the Creative Commons Attribution International License (CC BY 4.0).

http://creativecommons.org/licenses/by/4.0/

\begin{abstract}
This article aims at showing the current practice in the Gulf of Guinea to enhance the security of merchant vessels in the region, by using the local integrated maritime strategy (EIMS) of government agencies. Following the increase in the spate of attacks in the GOG region, commercial vessels have been keen on adopting the use of Institutional and operational initiatives (IOI) taken at the national and regional levels in the framework of combating maritime crime (piracy). However, in the context Gulf of Guinea, there is evidence suggesting that most unlawful acts against vessels in the region, irrespective of their nature or location, are erroneously being classified as acts of piracy. There is a need to raise awareness and involve civil society in current discussions and programs on maritime security. According to the current situation, maritime security is widely regarded as a military issue, involving only local communities in coastal areas, which are suffering the greatest threat from sea. In fact, in a strict sense, maritime security is not a military or law enforcement issue; on the contrary, it should include a wide range of social, environmental, institutional, political and economic issues in a comprehensive way. Thus, placing maritime security outside the armed forces will help to launch a new debate on how coastal communities can benefit (or pose a threat) from maritime safety and security. As an alternative, countries such as Togo and Nigeria, in collaboration with the Institutional and operational initiatives provide vessels an extra layer of protection. This article seeks to explore the current trend in the GOG and the host of sensitive legal issues they may raise. The article first identifies the features of models before assessing them against international norms in other to highlight specific legal, institutional and operational concerns. Finally some remarks will be made through a conclusion based on the normative and practical perspective of the article.
\end{abstract}

\section{Keywords}

Gulf of Guinea, Togo, Law Enforcement, Security, Piracy 


\section{Introduction}

Maritime Security is of serious concern to the shipping industry because of the continuous piracy in the Gulf of Guinea. The case is alarming in country such as Togo where acute needs in security measures need particular attention. In this perspective shipping company's call for government's attention to eradicate such an economic and life wasting challenges. Legal and political commitments are required for the implementation of the existing polity as well as the reinforcement of the institution involved in maritime piracy management in Togo. Furthermore the Gulf of Guinea for a little less than decade has remained under the international community radar due to the violent and systematic nature of piracy and armed robbery in the region (Hassan, 2016). This has raised the question of how do the Gulf of Guinea states conduct their cooperation to fight piracy? In fight against piracy what kind of legal instrument and operational Togo have put in place? And how they do apply the international law regime and institutional regulations?

The International Maritime Bureau (IMB, 2013) in its first quarter report of 2013 shows 31 pirate attacks in the Gulf of Guinea, specifically in the waters off Nigeria, Togo, Benin and parts of Ghana. Besides, The International Maritime Bureau (IMB) reported 201 piracy and armed robbery incidents worldwide in 2018. There is a marked rise in attacks against ships and crews around West Africa, with the Gulf of Guinea accounting for all six hijackings (2017 \& 2018), 16 (2017) of 18 (2018) ships fired upon, 91 (2017) of 141 (2018) hostages held, and 75 (2017) of 83 (2018) seafarers kidnapped for ransom worldwide, ICC-IMB (2018). Whilst the reduction in the overall numbers is welcomed in 2019, the IMB-ICC is extremely concerned over certain spikes in different parts of the World. In 2019, an unprecedented number of crew was kidnapped from their vessels with 134 crew taken in 19 separate incident (IMO, 2018). The Gulf of Guinea accounts for over $90 \%$ of the global crew kidnappings and has increase than $50 \%$ year on year with $121 \mathrm{crew}$ taken in 2019 compared to 78 in 2018 . The kidnapping of crew is not just a phenomenon faced by one sector of shipping (IMO, 2019). All types of vessels have been targeted at various distances from coastline. For instance, in March 2019, a Malta flagged Tanker MT Histria Ivory was attacked by armed pirate around $17 \mathrm{~nm}$ SSE of Lomé, Togo at approximately 19:40 UTC [1]. Armed attacked and successfully boarded the vessel. Additionally, only 12 May 2019 a Togo flagged Chemical Tanker MT G Dona 1 was hijacked by armed persons while anchored at Lomé Anchorage, Togo at approximately 01:00 UTC (IMO, 2019). Furthermore on 04 November 2019, a Greek flagged Product Tanker MT Elka Aristote was attacked by armed persons around $9 \mathrm{~nm}$ SSE of Lome, Togo at approximately 02:40 UTC (IMO, 2019).

Besides, it must be acknowledged that the Gulf of Guinea area in question is a high risk one and appropriate measures to protect the crews must be provided. Therefore, to reflect the seriousness of the problem of piracy, commercial vessels desiring to reduce the economic burden created by attacks in the region have been keen on applying an integrated maritime strategy (EIMS) model operating 
in the other piracy hotspots (Rider, 2013).

This article explores the contemporary practices of state provision with a specific focus on Togolese experience of an extra layer of security to commercial and civil vessel in the GOG. It examines the impact of these trends within the context of existing international law and practice relevant to maritime security. The article contends that these practices which involve an EIMS in some respect, stir up concerns due to ambiguities that attend the engagement of these service. These ambiguities highlight the intricate nature of the global security architecture in the maritime domain. In spite of these obscurities, the current practice contributes to security in the GOG.

The next section shows and analyzes the Contemporary maritime piracy through the integrated model analysis and their result. Section 3 examines the local security protection model that exists in the region in general and Togo in particular. This section describes the general workings of the local security model. Section 4 undertakes an exploration of the impact of the existence of these trends to maritime security in the GOG. Section 5 provides a contribution to enhance Maritime Security. A useful conclusion was made in Section 6.

\section{Maritime Piracy in the Gulf of Guinea}

\subsection{Contemporary Maritime Piracy}

As early as 2009 , while the international community was earnestly engaged in combating piracy off the coast of Somalia, commercial vessels, especially product tankers, already began to express serious concern over the spate of attacks in the gulf of the guinea (Swift, 2009), Since then the waters within the Togolese, Beninese, Nigeria axis of the region have been regarded as high risk areas, as dangerous if not riskier than the waters of the coast of Somalia. Most of the attack in Togo happen in 2012 (see Table 1). Contemporary piracy and armed robbery against ships in the GOG region which had its roots in the oil rich yet impoverished communities of the Nigeria delta in Nigeria now present a lucrative business of sea robbery, petrol piracy and kidnapping for ransom (ECSA-ETF, 2013), while many of the operation within the region connected to Nigeria; the country currently ranks among the top five location for reports of violent maritime crime globally (Ali, 2015). According to ICC-IMB, there were total of 1 attack for Togo in 2018 and 3 attack in 2019 (IMO, 2019). Table 2 shows the Location of actual and attempted attacks 2012-2019 in Togo.

\subsection{Integrated Model Analysis}

The analysis described the incidents of pirate attacks that occurred from January 2012 to December 2019, and this information comes from the ICC International Maritime Bureau (IMB) Piracy against Ships annual reports 2012-2019. The IMB reports embody the time and date of the Incident, the crew category members and their rank etc. once statistics assortment was far-reaching, the information was set up into applicable tables and graphs, and portrayed within the following section. 
Table 1 provides a list of the geographical location of actual and attempted attacks from 2012 to 2019 dominated by incident in Africa and especially in the gulf of guinea and Togo. Analysis of the result will illustrate trend in the persistence period.

Table 1. Location of actual and attempted attacks 2012-2019 in Africa.

\begin{tabular}{|c|c|c|c|c|c|c|c|c|}
\hline & 2012 & 2013 & 2014 & 2015 & 2016 & 2017 & 2018 & 2019 \\
\hline ALGERIA & 1 & 0 & 0 & 0 & 0 & 0 & 0 & 1 \\
\hline ANGOLA & 0 & 0 & 1 & 0 & 2 & 1 & 0 & 0 \\
\hline BENIN & 2 & 0 & 0 & 0 & 1 & 0 & 5 & 3 \\
\hline CAMEROON & 1 & 0 & 1 & 1 & 0 & 0 & 7 & 6 \\
\hline DRC & 2 & 0 & 1 & 3 & 2 & 0 & 1 & 1 \\
\hline SAO TOME & 0 & 0 & 1 & 0 & 0 & 1 & 0 & 1 \\
\hline EGYPT & 7 & 7 & 0 & 1 & 0 & 0 & 0 & 0 \\
\hline GABON & 0 & 2 & 1 & 0 & 0 & 0 & 0 & 1 \\
\hline GHANA & 2 & 1 & 4 & 2 & 3 & 1 & 10 & 3 \\
\hline GUINEA & 3 & 1 & 0 & 3 & 3 & 0 & 0 & 2 \\
\hline GULF ADEN & 13 & 6 & 4 & 1 & 0 & 3 & 1 & 0 \\
\hline IVORY COAST & 5 & 4 & 3 & 1 & 1 & 3 & 1 & 0 \\
\hline KENYA & 1 & 1 & 0 & 2 & 2 & 1 & 0 & 1 \\
\hline LIBERIA & 0 & 0 & 1 & 2 & 0 & 0 & 0 & 2 \\
\hline MAURITANIA & 0 & 1 & 0 & 0 & 0 & 0 & 0 & 0 \\
\hline MORROCO & 0 & 1 & 1 & 0 & 1 & 0 & 0 & 2 \\
\hline MOZAMBIQUE & 2 & 2 & 1 & 1 & 1 & 2 & 0 & 0 \\
\hline NIGERIA & 27 & 31 & 18 & 14 & 36 & 33 & 48 & 35 \\
\hline RED SEA & 13 & 2 & 4 & 0 & 0 & 1 & 0 & 0 \\
\hline SIERRA LEONE & 1 & 2 & 1 & 0 & 0 & 4 & 0 & 1 \\
\hline SOMALIA & 49 & 7 & 3 & 0 & 1 & 5 & 2 & 0 \\
\hline SOUTH AFRICA & 0 & 0 & 0 & 0 & 1 & 1 & 6 & 3 \\
\hline TANZANIA & 2 & 1 & 1 & 0 & 0 & 0 & 0 & 0 \\
\hline THE CONGO & 4 & 3 & 7 & 5 & 6 & 0 & 0 & 0 \\
\hline TOGO & 15 & 7 & 2 & 0 & 1 & 0 & 1 & 3 \\
\hline SENEGAL & 0 & 0 & 0 & 0 & 0 & 1 & 0 & 0 \\
\hline EGQUATUO GUINEA & 0 & 0 & 0 & 0 & 0 & 0 & 0 & 1 \\
\hline
\end{tabular}

Source: International Maritime Bureau: Piracy and Armed robbery against ship between January 2012 to December 2019 (ICC IMB) annual report.

Table 2. Location of actual and attempted attacks 2012-2016 in Togo.

\begin{tabular}{ccccccccc}
\hline TOGO & 2012 & 2013 & 2014 & 2015 & 2016 & 2017 & 2018 & 2019 \\
\hline & 15 & 7 & 2 & 0 & 1 & 0 & 1 & 3 \\
\hline
\end{tabular}

Source: International Maritime Bureau: Piracy and Armed robbery against ship between January 2012 to December 2019 (ICC IMB) annual report. 
According to Figure 1, it was determined that Angola is an area of low risk; there is hardly any reported incidents of attacks of their coasts, and the trends on the neighboring coasts are also limited; the hijacking of the tanker Kerala in February 2014 was the major incident of Angola.

Incidents in and around the Democratic Republic of the Congo, the Republic of the Congo, Gabon, Gambia, Ghana, Guinea-Bissau, Liberia, Sao Tome and Principe, and Senegal are limited to theft from ships in ports and anchorages, as well as occasional robberies in territorial seas.

Attacks off the coasts of Cameroon and Equatorial Guinea have declined substantially since 2012, thus removing these two states from a high-risk ranking. It was determined that the declines in 2014 and 2015 were the result of the increased naval activities by the Nigerian Navy and the coast guard. Nigeria, as the regional economic power, has developed some initiatives against maritime criminals and pirates in the region.

Despite these initiatives, there was also a significant rise from 14 to 36 incidents from 2015 to 2016, keeping a similar level in 2017 with 33 incidents. In parallel, the Gulf of Guinea recorded a high level of piracy incidents in 2016 and kept at a similar level in 2017 as well.

As a result, in 2017, most of the attacks in the Gulf of Guinea were a result of boarding with some due to being fired upon and attempted, but not successful, hijacking. So, there was no successful attack in the Gulf of Guinea. Lagos in Nigeria is among those with three or more reported incidents with almost all the attacks/attempts conducted while the ships were underway. There was no killed crew, but in almost all of the attacks, there were kidnapped crews in Nigeria. In addition, piracy incidents in this area also tend to be more dangerous because they are often well armed and more violent. Again, they may kidnap and/or injure the crews. All waters in/off Nigeria are risky; even up to 170 nautical miles from the coast, attacks have been reported in 2017.

Furthermore Somalia and the Gulf of Aden also recorded a significant incident in 2012 with a result of 49 attacks.

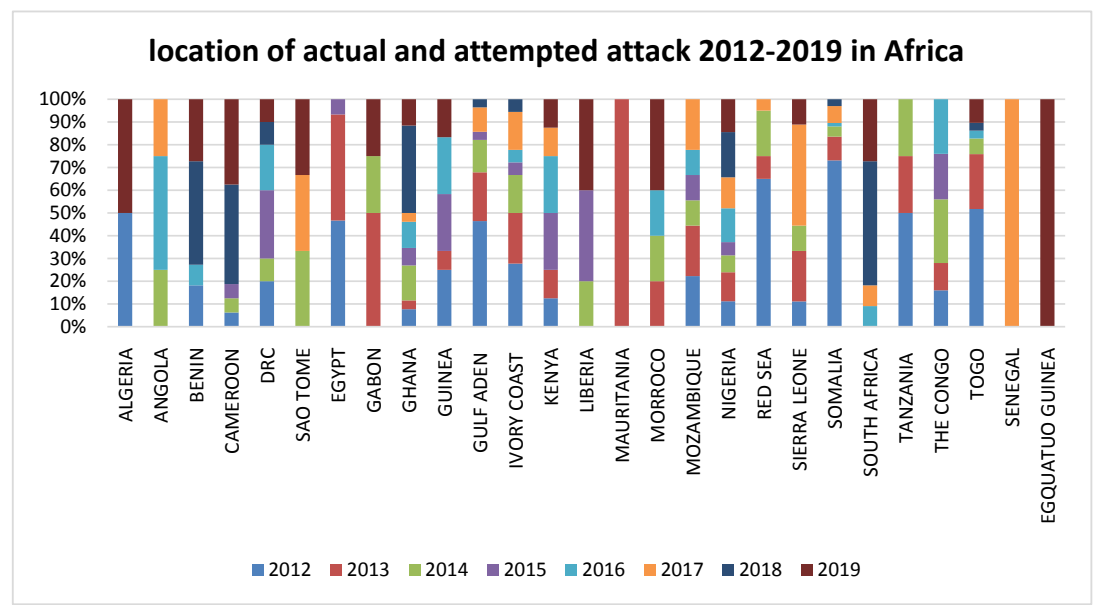

Figure 1. Location of actual and attempted attack 20122019 in Africa. Source: Author's own elaboration. 


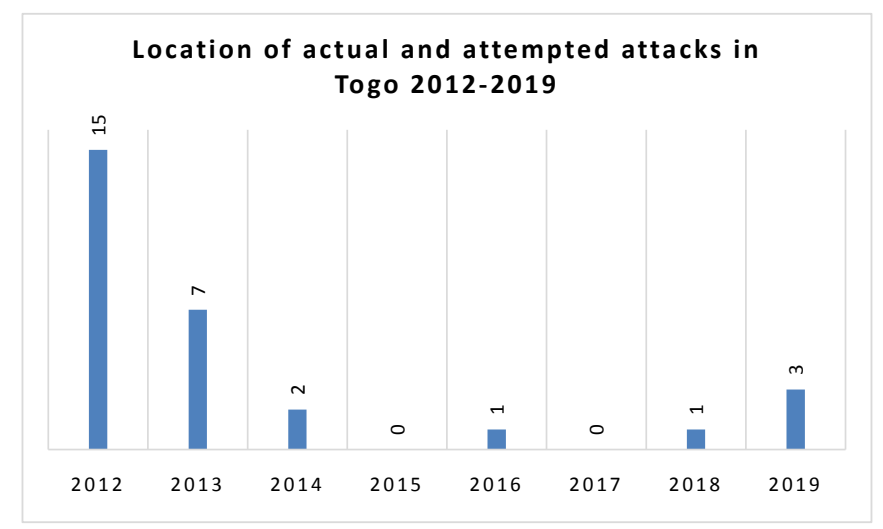

Figure 2. Location of actual and attempted attack 2012-2019 in Togo. Source: Author's own elaboration.

According to Figure 2, it was determined that there was a significant incident in 2012 concerning the number of piracy in Togo with a result of 15 attacks in the gulf of guinea. There was 7 attack in the year 2013 and 2 attack in 2014. The year 2016 recorded 1 attack. Togo, during 2016-2017 managed two (02) cases of real crisis and proceeded with the launching of the mixed patrols. These interventions made it possible to rescue on 28 March 2016. The ship SAMPATIKI IMO 9405772 flying the Liberian flag and recorded by the OMA company, which was the victim of an act of piracy in Nigerian Waters and the freezer fishing vessel F/V YELE flying Sierra Leonean flag IMO 6607666 and recorded by INTER TRANS MARITIME Company, suspected of IUU fishing activities. Besides we notice again 1 attack in 2018 and 3 attack in 2019.

\subsection{Presentation of the Result}

The results look at the arms and violence reported to have been used against seafarers in Table 3 and Figure 3. As represented in Table 3, line blue (Figure 3), there was 4 assaulted by the year 2012, in year 2013 indicates 0 assaulted and 1 from the year 2014. However the number of this increased in 14 assaulted in the year 2015 with the difference of 1 to 14 . The year 2015 had recorded 33 a decline by 29 assaults from the previous year. It is also indicate that seafarers are being in assaulted with recording 5 and 6 in the year 2016 and 2017. There are no reported in 2018 and so far 3 in 2019. Also represented in Table 3, 585 taken to hostages by the red lines (Figure 3) in 2012; this declined the following year (2013) to 304, a decline of 281 hostage. However, this increases in 2014 to 442 being taken in hostage. In the year 2015 the hostages decrease to 271, and 151 in the following year (2016). The number of seafarers taken in hostage reported in the year 2018 was 91 but this increase by 141 in the following. The year 2019 showed a decreased by 82 , so 59 hostages were recorded. The year 2015 indicates 97 knives used, an increase by 14 used from the previous year. The figure also represent by the yellow line (Figure 3), the number of kidnapping was 26 in 2012 but increase to 36 in 2013. However it decreases respectively to 9 and 19 in 2014 and 2015. The year 2016 recorded 62, 75, 83 and 134 in 2016, 2017, 2018 
and 2019. It is represented that seafarers injures (grey line, Figure 3 ) have decrease from 28 in 2012 to $21,13,14,8,6,8,7$ respectively during the year 2013, $2014,2015,2016,2017,2018,2019$. It is also represented the number of seafarer's that were being killed are $6,1,4,1$, respectively during the years 2012-2015. No killing has been reported in 2016 and 2018. There are respectively reported 3 in 2017 and 1 in 2019. No missing in 2012 and 1 missing respectively in 2013 and 2014. No missing to 2015-2019. There are respectively reported $13,10,9,14,10$, 9, and 6 from 2012 to 2019.

According to the rate of killings, torture inflicted to crew members held hostage through their different equipment and abordage use as seen in Figure 3 and Table 3 and attacks in the sea related to piracy and armed robbery, the role of the international community to set an eye and oversee what is going on in the gulf and strategize on ways to help West African especially Togolese community to tackle the situation. Majority of the state in the region choose to use Institutional and operational initiatives (IOI) taken at the national and regional levels in the framework of combating maritime piracy. In place of (IMs) services involving the use of (IOI), new practice emerged in the GOG involving the use of state security personnel providing extra protection for commercial vessels and civil vessel and the three organs which are the high council for the Sea under the head of the State authority, the office of the Council for the sea and the maritime Prefecture.

Table 3. Statistics of types of arms used during attacks, January-December 2012-2019.

\begin{tabular}{ccccccccc}
\hline Types of Arms & 2012 & 2013 & 2014 & 2015 & 2016 & 2017 & 2018 & 2019 \\
\hline Guns & 113 & 71 & 62 & 33 & 48 & 52 & 56 & 47 \\
Knives & 73 & 81 & 83 & 97 & 44 & 44 & 36 & 36 \\
Not stated & 104 & 109 & 93 & 108 & 96 & 80 & 104 & 74 \\
Other weapons & 7 & 3 & 7 & 8 & 3 & 4 & 5 & 5 \\
Total & 297 & 264 & 245 & 246 & 191 & 180 & 201 & 162 \\
\hline
\end{tabular}

Source: International Maritime Bureau between January 2012 to December 2019 (ICC IMB) annual report.

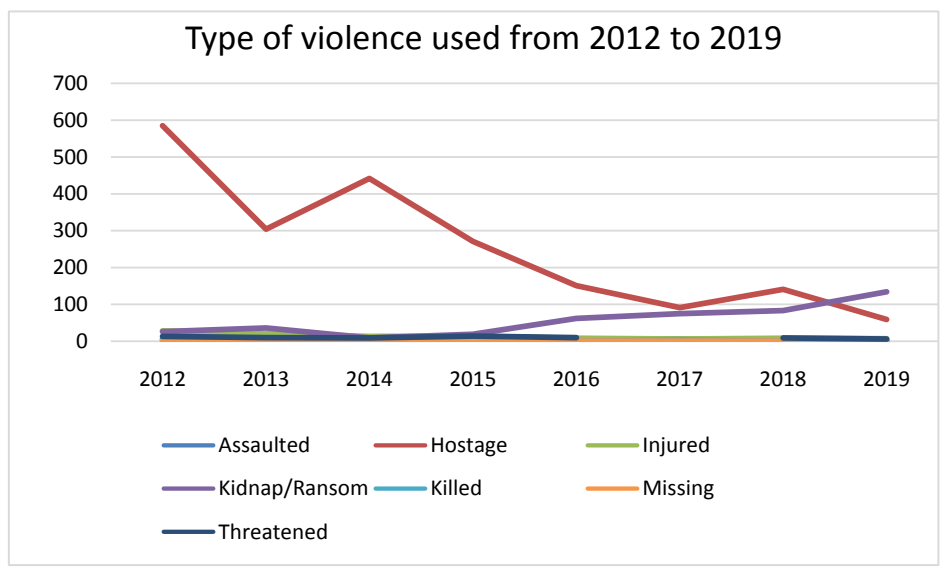

Figure 3. Types of violence upon seafarer's, January-December 2012-2019. Author's own elaboration. 


\section{The Local Security Protection Model for Maritime Protection in the GOG}

Two different practices involving the use of local security personnel to provide extra security to civilian vessels in the GoG: The operational level and the institutional level.

Regarding the operational level, the use of state security personnel is divided into two including embarked state security personnel and armed escort vessels. Concerning the institutional level we have the three organs which are the High Council for the Sea under the Head of State Authority, the office of the Council for the sea and the Maritime Prefecture.

\subsection{The Institutional Protection Security Model}

The severity of the pirate attack cannot be discussed without ending up with discussing the institutional situation in the gulf of guinea. The first concrete step of the West African sub-region towards building a joint maritime security and piracy under the umbrella of ECOWAS was initiated at a meeting of the ECOWAS Committee of Chiefs of Defence Staff (CDS) held in Cotonou in April 2010. A recommendation was made in subsequent meeting in January 2011 to ECOWAS Commission to develop a regional maritime security governance concept. The rise in incidents of piracy and related maritime insecurity, particularly in Benin, Côte d'Ivoire, Ghana, Guinea, Nigeria and Togo in 2012, raised concerns which led to a push for ECOWAS subcommittee on maritime security to develop an Integrated Maritime Security Strategy (EIMS). The five objectives of the EIMS strategic framework are to strengthen maritime governance, safeguard and secure the maritime domain, manage the maritime environment, optimize the ECOWAS maritime economy and to promote maritime awareness and research among members (Rider, 2013). A number of instruments have been established through the regional economic groupings, including regional coordination center and integrated maritime strategies. Prior to the Yaoundé conference, a number of tool were laid in place at the sub-regional level to address the issue of maritime insecurity. Among them, the Maritime Organization for the West and Central Africa (MOWCA) which was established in 1975 as the ministerial conference of the west and central African states on Maritime Transport. The MOWCA objectives are to help the regional and international community for handling all maritime matters of regional character. It puts emphasis on the establishment of a legal framework of cooperation for an effective fight against the threat related to marine pollution, safety and security.

In addition, in July 2001, the Gulf of Guinea Commission (GGC) was established by the treaty signed in Libreville by Angola, Congo, Gabon, Niger and Sao Tome and Principe. It is an institution cooperating among the countries broadening the Gulf of Guinea in order to defend their interest in conflicts related to maritime delimitation, boundaries, and exploitation of maritime resources. In terms of achievements, the MOWCA-MOU (2008) established the Sub-regional 
Coastguard Network for the West and Central African sub-region in July 2008 with the main goal to allow the parties in promoting and making joint efforts as far as their maritime activities are concerned, particularly those devoted to the protection of the human life, the enforcement of the laws, the improvement of safety and the protection of the environment. At the regional level, the Memorandum seeks the establishment of an integrated coastguard function network for West and Central Africa to develop and implement appropriate regional maritime security policies, regional legislation, practices, and procedures MOWCA-MOU (2008). At the national level, it recalled states obligation to prosecute, in accordance with relevant domestic laws, perpetrators of all forms of piracy and unlawful acts against seafarers, ships, port facility personnel and port facilities. The West and Central Africa economic groupings ECOWAS and ECCAS since the code of Yaoundé signature developed an integrated maritime strategy under an Interregional Coordination Center (ICC). The ICC as a body for coordination established a junction between the Central Africa Regional Maritime Security Centre with the French acronym (CRESMAO) and West Africa Regional Maritime Security Centre (CRESMAC). The coastal space of the two Economic grouping is subdivided into operational maritime zones whose activities are coordinated within Multinational Coordination Centers (MCC). The CRESMAC cover two MCCs notably zone A and D. Zone A is composed of Angola, Democratic Republic of Congo and Congo, while zone D comprises Cameroon, Gabon, Equator Guinea and Sao-tome. The CRESMAO cover three MCCs, which are representing the number of operational maritime zones under its governance. Zone E is composed of Nigeria, Togo, Benin; and Niger. Zone F comprises Ghana, Ivory Coast, Liberia, Sierra Leone, Guinea, and Burkina-Faso. The last zone G comprises Senegal, Gambia, Guinea Bissau, Cape Verde and Mali. The ECOWAS Commission picked Benin in 2015 to pilot Zone E considered as the most perilous sea zone in West Africa, and more grounded assurance endeavors are required in this area. For the other maritime zones in West Africa, Ghana took over the host nation function of zone F. Ghana centers will be operational and connected with the national maritime operation center of zone E, G, and the CRESMAO Zone G establishment is planned and not yet operational. In fact, the maritime centers are operational for any request and prosecution of persons involved in act of piracy, armed robbery, and other illicit crimes. It also plays the role of coordination and operational control, maritime law enforcement, sharing and networking of maritime information in the region and in Central Africa, MOWCA-MOU (2008).

In reality, the ICC remains an instrument in creation and does not have the operational capacity to effectively ensure the interregional coordination at national and regional level. In Michel LUNTUMBUE (2016) view, the MOWCA or the GGC through its long experience in the management of maritime and related issues could have claimed the role of coordination of the integrated maritime strategy attributed to the ICC, due to the growing interdependence of all 
maritime issues (trade, safety, environment among others). Similarly, a number of experts feel that instead of creating the ICC, the ECOWAS and ECCAS could have assigned the responsibility to the MOWCA to bridge the junction between the CRESMAO and CRESMAC. Furthermore, he suggested that the attribution of the assignments of coordination and operational capabilities to a limited number of bodies would reduce the financial constraint that weights on most of the Member States due to their belonging to several regional organizations, within which they are forced to finance through national contributions. Additionally, although Benin has been chosen to pilot zone E, the Economic weight, naval capacity as well as a great number of piratical assaults in Nigeria waters only, as the recent (2017) ICC IMB report has revealed raises questions about the choice of Benin instead of Nigeria owning a better naval capacity to pilot such a program.

At the national level, Togo is one of the Gulf States which has a maritime sector that constitutes a factor of developing its economy, but which is, however, threatened by the permanence of unlawful acts such as piracy and armed robbery at sea. Togolese institutional framework provides for a national authority responsible for State action at sea. Indeed, other ECOWAS States are also in that dynamic. Thus states such as Benin, Guinea, and Senegal are adopting their national strategies in phase with the ECOWAS Integrated Maritime Strategy. In regard Togo, its national agency is set up by the decree 2014-113/PR of 30 April 2014 on the sea. That agency is composed of three organs which are the high council for the Sea under the head of the State authority, the office of the Council for the sea and the maritime Prefecture. Each of these bodies is empowered by government decrees. For instance the High Council for the Sea (HCM) mission is to implement a device expanded to better organize and better coordinate services that have jurisdiction over Togo maritime domain and to respond to the safety, environmental and economic developments. Via the national body responsible for the action of the State at sea (ONAEM), it has the task to precisely define the maritime borders of the country, to improve the control of ships and boats, to combat pollution and erosion of coast promote fishing. Moreover in accordance with Decree No. 80-184/PR of 26 June 1980 on the organization of the Ministry of Commerce and Transport we have the Directorate of Maritime Affairs (DAM) (Attributions Act and Law No. 2016-028 of 16 October 2011 on the organization and functions) of Togo. The Maritime Bureau is responsible for the implementation of the National Maritime policy. In this regard, DAM's tasks include: navigational police functions in waters under national jurisdiction, monitoring the implementation of the International Ship and Port Facility Security Code, and the management of transport, maritime and port sectors. In fulfilling their duties, they have:

Ship management, floating installations, man-made islands, offshore and lagoon works, sunken ships and Maritime Mortgages:

- Participate in the management of oil and gas drilling platforms and other mining and petroleum equipment related to offshore and lake activities; 
- Participate in the management of the public sphere of oceans, lakes and rivers;

- Management of maritime professionals and seafarers;

- Participate in the protection and preservation of marine, lake and river environments;

- Participation in the implementation of the Maritime Labour Regulations;

- Resolving individual or collective conflicts;

- Port safety;

- Safety of navigation;

- Participate in search, rescue and work at sea, along lakes and rivers;

- Participate in monitoring and surveillance of marine and Mediterranean fisheries.

The organization and responsibility of maritime administration shall be stipulated by the Regulations.

In addition to these bodies, the decree 2015-026/PR of March 2015 establishing the national committee of maritime safety ensures the execution of the ISPS Code by the security authorities. A national Commission of maritime borders has been set up by the decree 2015062/PR of September 9th, 2015 under the Presidency order to proceed to the delimitation of the maritime boundaries between Togo and its neighboring countries namely: Benin and Ghana.

The GOG countries exercise varying degree of responsibility including protection of different zone in the sea. It generally within the determination of the flag state; in line with the responsibility to ensure security and safety of vessels under its nationality to establish laws and regulation applicable to such vessel. Such regulation may include the recognition of the use of operational and institutional service to ensure protection of the vessel in the high sea.

However, Egede (2016) reminded that a maritime security enforcement mechanism and the African judicial institutions dealing with marine issues are some limitations in the AIMS achievement. He argued that AU does not have an African joint naval task force and/or joint coast guard to deal with piracy and armed robbery at sea and other maritime security issues occurring in the African Maritime Domain. This re-opened the discussion about the limit of the institutional framework.

\subsection{The Operational Protection Security Model}

The operational protection involves the practice of the use of the affiliated armed patrol services (SAAPS) and state embarked security personnel (SESP) (ECSA-ETF, 2013). The affiliated armed patrol services (SAAPS) is defined as military asset engaged by the states to offer escorts for operation at sea for commercial vessels moving into and out of seawaters under their jurisdiction. Nonetheless the state embarked security personnel (SESP) consists of the placing armed security personnel on board civilian assets to protect operations at the sea while surrounded by the territorial water (ECSA-ETF, 2013). Additionally the use of (SESP) is sim- 
ilar to the vessel protection detachment (VPDs) employed off the coast of Somalia by states such as Netherlands and Italy (Hassan, 2016). However the local security personnel practice in the GOG is different. The security personnel belongs to the coastal country rather than flag state and the model occur within territorial waters rather than international water (Neri, 2012). In the case of (SAAPS) appropriate arrangement is made by the relevant government on behalf of the commercial vessel for the use of the state assets because the practice needs substantial investment in the acquisition of military platforms to undertake effective escort and patrol (UNSC, 2008). Additionally some states localize the method to specific area such as in Nigeria. It allows the armed escort services around the bonny river convoy. Furthermore Nigeria secure anchorage area where ship either anchor or conduct ship to ship transfer. At the same time, commercial vessel obtains SESPs by contracting, either directly or through other PMSCs in the region to act as intermediaries between the commercial vessel and the local state security personnel (Osinowo, 2015). Most of the time, the company usually suggests a connection with the naval forces of the various states. Several countries such as Togo, Benin practice the use of SESPs. According to Bergen Risk solution (2014) all vessels within Togolese territorial water are bound to have a shipping agency to issue prior information to the shipping agency. All vessel, shipping company, shipping agents shall be entitle to request special protection. Besides, Togo has operational resources through its navy and a new merchant shipping act to ensure the missions of the State at sea. From 2014, the Togolese National Navy had on some occasions intercepted hijacked ships in its waters. The Togolese National Navy owns from its foundation on 1 May 1976 two patrol vessels capable of stopping and capturing possible enemy ships, preventing them from approaching the coast, or even deterring them from entering territorial waters. Moreover, the 2016-004 Act of 11 March 2016 confers the bailiff qualification on the naval commander to determine the crime at sea. Additionally the Gendarmerie, the Fisheries Department, the Customs, the Immigration Services and the Anti-Drug Office are now operational. The threat is multidimensional between the fight against terrorism, trafficking, fishing or illegal immigration.

In Bueger's view, this development indicates the emergence of African maritime security communities. However, he pointed that a security community is characterized by a shared repertoire that includes a shared securitization, a joint enterprise to include shared projects of protection, and a high level of mutual engagement (Bueger, 2013). He added that strengthening maritime security will require significant technical competence as well as a considerable level of interagency and civil-military coordination, which is already difficult to achieve on the national level. Yaron Gottlieb, Senior Council at INTERPOL, suggested that a more holistic approach must be also taken to combat piracy from a law enforcement perspective.

Therefore, the typical nature of the Gulf of Guinea piracy has encouraged a shared responsibility of the member states in the framework of cross-border patrols, sharing law-enforcement intelligence, establishing and maintaining joint 
coordination centers through some legal, institutional and regional strategies subsequent to the UN Security Council recommendations.

\section{The Impact of the Trend of Maritime Security: Emergence of Unresolved Legal Concern}

Maritime Trade is an international activity, regulated by diverse national and international regulation. Therefore, the task facing coastal states like Togo, is to design and implement robust and sustainable measures that would buoy up maritime security and reduce sea piracy.

However the use of flag of convenience (the state can allow ship to register with other countries to take advantage of their limited regulations, lack of taxes and cheap labor) discourage Togo taking action against pirates. This further also obscures the identity of the owner making it difficult to determine whether the ship's owner affects the likelihood of getting attacked. States with flags of convenience are not naval or diplomatic powers so they do not have the resources to combat piracy. Furthermore the introduction in our law of a specific legal framework for the repression of piracy, which would make it possible to fully adapt Togo legislation to the stipulations of the Convention on the Law of the Sea is a major challenge. For instance, Art. 7 of the Criminal Code provides that: The Togolese courts are competent to judge any act qualified as crime by Togolese law committed abroad by a Togolese. They are also competent to try any offense committed abroad by a Togolese if the act is also punishable by the law of the country where it was committed. It will be the same if the accused did not acquire the Togolese nationality until after the fact pursued. The prosecution can be brought only on the complaint of the victim or the denunciation of the facts by the authority of the country where they were committed. Togolese courts are also competent to try foreigners who are outside the national territory guilty as perpetrators or accomplices of offenses against State Security, forgery of the seal of the State, counterfeit currency. However Article 105 of the Convention on the Law of the Sea, states that "Every States shall co-operate as far as possible in the suppression of piracy on the high seas or in any other place not under the jurisdiction of any State". Section 101 defines relatively accurately the misconduct.

The question therefore arises of the desirability of explicitly recognizing in our law a "universal jurisdiction" for the Togolese courts to try acts of piracy committed by foreign nationals on the high seas, whatever the nationality of the ship, persons or property that is the victim, as permitted by Article 105 of the Convention of the law by sea.

Currently, Togo law does not seem to recognize the possibility for the Togolese courts to try acts of piracy committed by nationals of another State in international waters and having committed no act against nationals.

One explanation suggests that lawmakers may not see a need for a modern anti-piracy law. According to Tom Syring, is noticed that because there is no international court or other international institution in existence which would 
have jurisdiction over the crime of piracy and hence, domestic proceedings are the only feasible alternative (Syring, 2011). As such he suggested that what is needed in any case is a comprehensive approach to modern piracy legislation, addressing evidentiary and implementation concerns and creating a broad basis of national jurisdictions with, as close as possible, similar approaches, procedures, and sentences for comparable acts of piracy until, perhaps, a future international institution for such a purpose may be established (Syring, 2011). He supports the idea that drafting more standardized, modern anti-piracy legislation, as a minimum floor for national prosecutions, would be a worthwhile endeavor in enhancing the prosecutorial regime to fight piracy (Syring, 2011). His suggestion of standardization of modern-anti piracy legislation is favorable to the need of harmonization of national laws in the Gulf of Guinea states seeking to implement their national legislation as recommended by the resolutions of the UN Security Council.

On the contrary, Ryan P. Kelly (2011) believe that consistent action by all states involved will require a framework by which to assess competing claims to jurisdiction, which will necessarily call for a reinterpretation of the Law of the Sea Convention (Kelly, 2011). For him, the Universal jurisdiction regime under UNCLOS article 105 has been misused in violation of the convention by states which exercised it by transferring pirates from one state to another. Pursuing this course of action despite the possibility that UNCLOS prohibits it without amending or distinguishing the convention, could significantly undermine its status. As a simple remedy, he suggests launching an advisory opinion by the ITLOS clarifying the matter could suffice as a binding decision on state parties based on article 138 of the Rules of the ITLOS. The tribunal could determine that UNCLOS poses no barrier to transfers of suspected pirates, perhaps under certain conditions. If it decided otherwise, state parties could add reservations, understandings, or declarations to their signing and ratification. Barring these avenues of recourse, state parties could propose an amendment to the text of article 105 based on article 312 of the UNCLOS. Changing the language of that provision would nullify the effect of the commission's commentary. Such amendments might include language similar to SUA's punish or extradite provision. They might add to the current clause allowing the courts of the capturing state to determine punishment by also allowing it to determine whether to punish or extradite to a state with a stronger jurisdictional claim. Making UNCLOS compatible with state practice and the other related instruments would promote the creation of clear legal guidelines for addressing piracy. Such guidelines would enable swift and effective punishment for convicted pirates in order to provide an effective deterrent for other would-be pirates, Kelly Ryan (2011) Aside from the concerns connected to establish principles; the practices in Togo are operate in manner that reflects inconsistencies due to a failure to regulate processes. For instance in the case of armed of escort service, the ship ordinary belongs to the armed forces of the embarked state and are mark as such. Consequently in terms of human resources, the number of maritime units to ensure 
the implementation of the law of the sea does not meet the needs. Therefore, the military personnel will be affected by many retirements in the years to come. Renewal of military personnel must therefore be anticipated now. In addition; the available units are assigned exclusively to the protection of the coasts and thus do not allow to control the whole of the maritime space under Togolese sovereignty ... Also is unclear whether security personnel during the protection of the vessel, they are solely engaged for that purpose or are allowed to bearing other connected policing roles such as the arrest and detention of suspected criminals. Engaging SESPs on boards a vessel amends the established principle that the master of commercial ship is responsible for overall security and safety of his vessel OBP (2017). Therefore considering that international law prohibit merchant vessel from performing enforcement operation in the high sea, Bergen Risk Solution (2014), in the event of attack it is difficult to argue that the local security personnel will consider the opinion of the master on how to handle the situation. Furthermore, in term of material, sometimes when the personnel provide the services their status remains unclear because their presence dependent on contractual arrangements with PMSCs who in turn facilitates the GoG practice. From this perspective, the provision of an extra layer of protection involving economic benefit to the state may ultimately serve as a discouragement of improving the general security level. It can also create room for the possibility of providing preferential treatment to civilian vessel that can afford to part with extra cash. Both models involve acquiring protection fees (see Table 4 below). Several provisions of Togolese law may therefore be envisaged to establish the jurisdiction of the Togolese courts to initiate proceedings and to try the perpetrators of offenses committed outside the territory.

Table 4. Cost summary for 7 days operation using SESP.

\begin{tabular}{cccc}
\hline \multirow{2}{*}{ Description of service } & \multicolumn{2}{c}{ Cost Summary (US Dollars) for 7 day Operation } \\
\cline { 2 - 3 } & Benin & Nigeria & Togo \\
\hline Coordinator's fee & 474.97 & 2450.00 & 180.65 \\
4 Armed guards & $10,638.66$ & 4550.00 & 8240.00 \\
Embark/Disembark via shuttle & 2500.00 & 2500.00 & 2500.00 \\
Naval Admin cost per operation & - & 2750.00 & - \\
Maritime liaison security officer (MLSO) & 42,000 & 42,000 & 42,000 \\
\hline
\end{tabular}

Source: Ocean Beyond piracy, Coastal state embarked personnel.

In addition, from the guidelines drawn by the national strategy of Togo for the sea and the coastline, specific objectives are needed to be determined and adaptations of legislation and regulations should continue to provide the best possible support for activities at sea. As a primary legal document conducted by the government, the merchant shipping act has to be update to ensure the missions of the State at sea. Moreover, the different treaties, codes, and memoranda of understanding that will have to be ratified induce a lengthy legislative process. 


\section{Contribution to Enhance Maritime Security}

Maintaining the safety of waterways and strategic chokepoints is beyond the capacity of one state (Onuoha, 2009). That is why cooperation between states and national navies is needed, especially in a world where non state actors such as pirates can have access to arms, intelligence and high-tech equipment, see Figure 4. A new integrated maritime strategy in term of institutional and operational security in the Gulf of Guinea provide a real time of protection by signed various multilateral agreements in favor of a good cooperation and coordination in pursuing pirates and by providing armed guards both on board of the vessel and as escorts. This strategy is effective in reducing the piracy attacks. Among the strategies against maritime piracy in the region, IMO strategy is
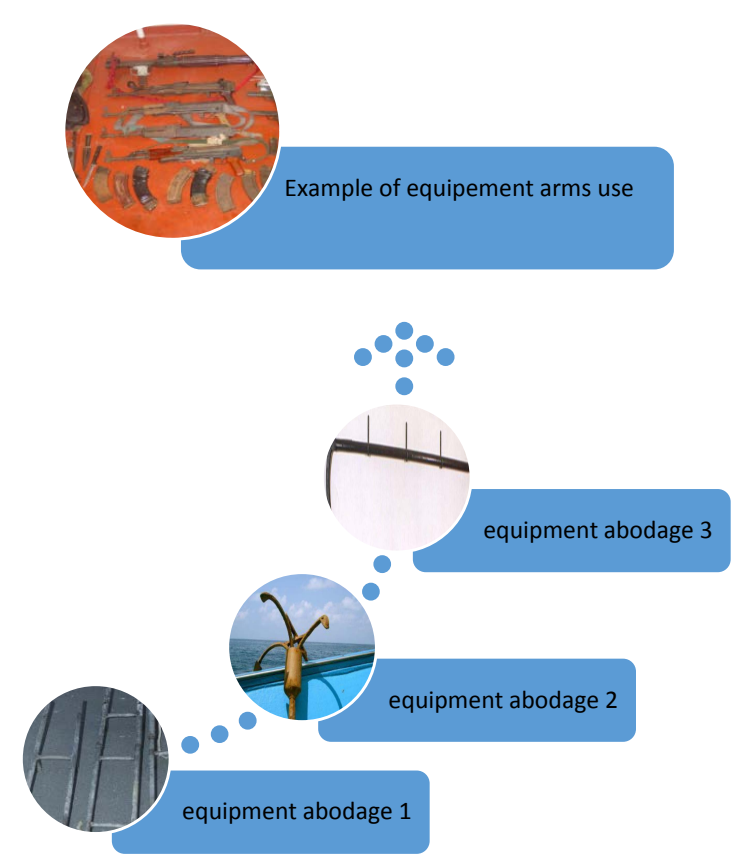

Figure 4. Equipment and abordage use. Source: Author's own elaboration (2020).

such a dynamic and helpful program that states must adhere to. It does not only help the Gulf states to fully implement the Yaoundé code of conduct but also revise their national legislation to criminalize piracy, attacks against ships and other illicit activities at sea. That corresponds to the UN Security Council recommendations in the region. In addition, IMO gives coordinating structures and procedures as well as technical and logistical support to states. Furthermore, Regarding the Charter on maritime safety and security and development in Africa, the Lomé Charter adopted in 2016 is a momentous document in three main ways. Firstly, it moves the African maritime security agenda from a mainly soft law, non-binding approach, as reflected in vital instruments such as the 2009 Djibouti Code of Conduct, the 2013 Yaoundé Code of Conduct or the 2050 Africa's Integrated Maritime Strategy (AIM Strategy) adopted in 2014, to a 
hard law, legally binding treaty approach. Secondly, it seeks to accentuate the crucial linkages between maritime security and safety and the huge prospects of utilizing the marine spaces and resources as a key driver of Africa's economic and social development. Thirdly, it provides a legally binding definition, though framed of the in rather general terms, of Blue/Ocean Economy (Kanehar, 1999). Therefore, the GOG states must be encouraged to fully adhere to such helpful and huge program. As far as the Architecture of the Gulf of Guinea maritime security is concerned, each state must in its own zone play the role of leader to welcome that strategy. However, a regional state such as Togo has made maritime security among their priorities through the established national strategy and institutions at the national level which deals with maritime threats. This approach can be effective countermeasure when attacks are detected as criminals, and still making their approach on vessel and not after they have successful board (Liwang, 2017).

\section{Conclusion}

Maritime security has remained a challenge in the GOG in recent times. Moreover the emergence of trend (piracy) within established international principles and practices illustrate the complexity of the general framework for maritime security not just in the region but also globally. In response, state in the region adopted the practice of IMS by creating operational, institutional and legal concern. These article, are presently a significant part of how state like Togo respond to the problem of Contemporary piracy in the region, as such deriving maximum benefit require careful consideration of and attention to the concerns. Although the establishment of the IMS in Togo would not be a definitive solution to avoid piracy in the gulf of guinea. Aside the national maritime strategy cannot be effectively implemented without the allocation of dedicated resources. Additionally it appears from the international legal regime that piracy is a crime subject to Universal Jurisdiction over which all state can exercise jurisdiction. A crime of such qualification, under a so widely ratified convention such as UNCLOS need to provide exactly what jurisdictional step a state should take and what sentence to impose on piracy perpetrators. Furthermore a real focus must be a grant of jurisdiction exercise especially under the UNCLOS article 105 which does not conform to states practice. Somalia case and now the Gulf of Guinea demonstrate it properly. Any further amendment or advisory opinion should consider this matter which is valuable to deal with piracy and related crimes. While these issues still not yet dealt with, it is arguably, however, to encourage states to fully ratify and implement in their national legislations key conventions such as UNCLOS, SUA protocol (2005) which framed a territorial-based approach to deter unlawful acts at sea and enforce the ISPS Code as well. Peter Chalk, Laurence Smallman, and Nicholas Burger (2009), advocated an appreciation of the need for national government to enact and enforce domestic laws congruent with the responsibilities imposed by the international 
agreements such as UNCLOS and SUA Convention. They argued that at present there is no single point of reference that details which states actually have the necessary laws and statutory provisions to execute their obligations under these two accords, and this is certainly something that could be usefully addressed. They suggested that Global conventions such as UNCLOS could also be accompanied (rather than replaced by additional sub-regional agreements that impose greater obligations and responsibilities on signatory states).

\section{Acknowledgements}

I would like to express my gratitude to Professor 王国华, my supervisor, for her painstaking engagement throughout the learning process of this article. I thank her for his useful suggestions and remarks which have become the embodiment of the document. I would further thank Professor 高俊涛 for their illuminating views on a number of issues in this article.

\section{Conflicts of Interest}

The authors declare no conflicts of interest regarding the publication of this paper.

\section{References}

African Intergraded Maritime Strategy AIMS (2014). Para 7.

Ali, K. (2015). The Anatomy of Gulf of Guinea Piracy. Naval War College Review, 68, 179-181.

Bergen Risk Solution (2014).

Bueger, C. (2013). Communities of Security Practice at Work? The Emerging African Maritime Security Regime. African Security, 6, 297-316. https://doi.org/10.1080/19392206.2013.853579

Chalk, P., Smallman, L., \& Burger, N. (2009). Countering Piracy in the Modern Area. Rand Corporation Ellen Q.P.M.

Council of the European Union (EU) (2014). European Union Maritime Security Strategy, 11205/14, Brussels, 24 June 2014.

Egede, E. (2016). Institutional Gaps in the 2050 Africa's Integrated Maritime Strategy. Iilwandle Zethu Journal of Ocean Law and Governance in Africa, 2016, 1-27.

European Community Ship-Owner Association European Transport Federation ECSA-ETF (2013). Piracy in East and West Africa, ECSA-ETF Joint Statement. http://www.ecsa.eu

Hassan, S. M. (2016). Current Arrangements to Combat Piracy in the Gulf of Guinea Region. An Evaluation in Journal of Maritime Law and Commerce, 47, 171-180.

International Maritime Organisation (IMO) Assembly (2019). Resolution 1025, Code of Practice for the Investigation of Crimes of Armed Robbery against Ships. A 26/Res. 1025 (31 December 2019) (Code of Practice) Annex 2.2.

International Maritime Organization (IMO) Assembly (2013). Resolution 1025, Code of Practice for the Investigation of Crimes of Armed Robbery against Ships.

Kanehara, A. (1999). The Japanese Legal System Concerning Innocent Passage of Foreign 
Vessels 1990-1998. Japanese Annual Journal International Law, 42, 105.

Kelly Ryan, P. (2011). UNCLOS But No Cigar: Overcoming Obstacles to the Prosecution of Maritime Piracy. Minnesota Law Review, 95, 2285.

Liwang, H. (2017). Piracy off West Africa from 2010 to 2014: An Analysis. WMU Journal of Maritime Affairs, 2017, 398.

Luntumbue, M. (2016). The Long March of African Maritime Safety and Security in the Gulf of Guinea. Group for Research and Information on Peace and Security.

Maritime Organization of West and Central Africa, Memorandum of Understanding MOWCA-MOU (2008). XIII General Assembly 08/8.

Neri, K. (2012). The Use of Force by Military Vessel Protection Detachment. The Law of the War Review, 51, 81.

Ocean Biyond Piracy (OBP) (2017). Coastal State Embarked Personnel. OBP Issue Paper.

Onuoha, C. (2009). Sea Piracy and Maritime Security in the Horn of Africa: The Somali Coast and Gulf of Aden in Perspective. African Security Review, 18, 31-44.

Osinowo, A. (2015). Combating Piracy in the Gulf of Guinea (pp. 5-6). African Security Brief No. 30.

Rider, D. (2013). Action Plan on Integrated Maritime Strategy, NEPTUNE Maritime Security on www.neptunemaritimescurity.com.

Swift, P. (2009). Letter Addressed to the Secretary General IMO. Intertanko.

Syring, T. (2011). A Pirate and a Refugee Reservations and Responses in the Fight against Piracy. ILSA Journal of International \& Comparative Law, 17, 437-455. 